\title{
Variação Linguística e Ensino: crenças e atitudes linguísticas
}

Linguistic VARIATION AND TEACHING: LINGUISTIC BELIEFS AND ATTITUDES

Elyne Giselle de Santana Lima Aguiar VITÓRIO*

Resumo: Tendo em vista que a escola é um espaço em que se constroem crenças e se moldam atitudes, verificamos como os formadores da consciência linguística e disseminadores dos discursos sobre língua concebem o processo de ensino de Língua Portuguesa. Para tanto, analisamos as crenças e atitudes dos alunos de Letras, futuros professores de Língua Portuguesa, sobre língua, variação e ensino. Para a descrição e análise dos dados, seguimos os pressupostos teórico-metodológicos da Sociolinguística Variacionista (LABOV, 2008) e dos estudos sobre crenças e atitudes linguísticas (CYRANKA, 2007; BARBOSA; CUBA, 2015; BOTASSINI, 2015; SILVA; BOTASSINI, 2015). Nossos dados revelam que, apesar de os alunos ainda acreditarem na associação entre língua e gramática normativa, apresentam crenças e atitudes positivas em relação à pedagogia da variação linguística, defendendo a ideia de que é papel da escola não só reconhecer, mas também trabalhar a diversidade linguística. Também observamos uma avaliação negativa em relação ao ensino de língua nas escolas, que, segundo os alunos, é centrado apenas na norma-padrão.

Palavras-chave: Ensino de Língua Portuguesa. Crenças linguísticas. Atitudes linguísticas.

\footnotetext{
* Mestra em Linguística pela Universidade Federal de Alagoas (2008). Doutora em Linguística pela mesma Universidade (2012). Realizou estágio de Pós-Doutorado em Letras Vernáculas na Universidade Federal do Rio de Janeiro (2013) PDJ/CNPq e em Letras e Linguística na Universidade Federal de Alagoas (2014) PNPD/Capes. É professora da Universidade Federal de Alagoas, Campus do Sertão, e coordenadora do grupo de pesquisa A Língua Usada no Sertão Alagoano - Lusa. Contato: elyne.vitorio@gmail.com.
} 
Abstract: Considering that the school is a space in which beliefs are built and molds attitudes, we see how the formators of the linguistic conscience and disseminators of the discourses on language conceive the process of teaching Portuguese Language. Therefore, we analyze the beliefs and attitudes of students of Letters, future teachers of Portuguese Language, on language, variation and teaching. For the description and analysis of the data, we adopted the theoretical and methodological assumptions of Sociolinguistic Variationist (LABOV, 2008) and studies on linguistic beliefs and attitudes (CYRANKA, 2007; BARBOSA; CUBA, 2015; BOTASSINI, 2015; SILVA; BOTASSINI, 2015). Our data show that although students still believe in the association between language and normative grammar, they present positive beliefs and attitudes towards the pedagogy of linguistic variation, defending the idea that it is the school's role not only to recognize but also to work on linguistic diversity. We also observed a negative evaluation regarding language teaching in schools, which, according to the students, is centered only on the standard norm.

Keywords: Teaching of Portuguese Language. Linguistic beliefs. Linguistic attitudes.

\section{Introdução}

A língua como objeto social, variável e passível de sistematização constitui a maior contribuição da Teoria da Variação e Mudança Linguística para os estudos da linguagem. Ao adotar essa concepção de língua, os estudos sociolinguísticos partem dos pressupostos de que há diferenças linguísticas entre as normas estabelecidas pelas gramáticas normativas e os reais usos da língua, de que a variação linguística não é aleatória, mas condicionada por restrições linguísticas e extralinguísticas, e que o ensino de Língua Portuguesa trabalhe com uma metodologia que conceba a língua como um sistema inerentemente variável.

As pesquisas empreendidas na Sociolinguística Variacionista, referentes à descrição e à análise linguística, muito têm contribuído não só para o mapeamento sociolinguístico do português brasileiro, mas também para o desenvolvimento de políticas educacionais, levando ao ambiente de sala de 
aula a ideia de que o ensino prime por uma abordagem que leve em consideração o funcionamento real da língua, tendo em vista que tanto a língua falada quanto a língua escrita são constituídas discursivamente por formas linguísticas que competem entre si, ou seja, fala e escrita são historicamente situadas e heterogêneas.

Nesse contexto, o ensino de Língua Portuguesa na escola deveria aceitar e trabalhar a diversidade linguística, o que consiste na aceitação da cultura e do falar próprio do aluno e do seu grupo social. Essa aceitação tende a ampliar o respeito para com as outras culturas de linguagem, evitando e combatendo o preconceito linguístico e a consequente exclusão social decorrentes do uso de formas linguísticas não prestigiadas socialmente. $\mathrm{O}$ ambiente escolar deve, portanto, primar por uma educação linguística que trabalhe a língua como um sistema inerentemente variável, como um sistema que varia e muda no tempo e no espaço.

Tendo em vista essas considerações e partindo do pressuposto de que a escola é um espaço em que se constroem crenças e moldam atitudes, consideramos pertinente verificar como os formadores da consciência linguística e disseminadores dos discursos sobre língua concebem os conceitos de língua, variação e ensino durante o processo de formação acadêmica. Para tanto, analisamos quais são as crenças e atitudes dos alunos do curso de Letras quanto ao processo de ensino/aprendizagem de Língua Portuguesa, tendo em vista que suas crenças e atitudes linguísticas influem nas decisões voltadas à questão do ensino.

Nosso ponto de partida é o de que a construção e a abordagem de uma pedagogia linguística que considera a língua como um sistema historicamente situado e heterogêneo, como um sistema constituído por um conjunto de variedades, depende de crenças e atitudes linguísticas que se constroem e fomentam a respeito das variedades da língua em uso, uma vez que a língua falada e a língua escrita dependem da adequação ao contexto linguístico. Nesse sentido, crenças e atitudes linguísticas influem tanto no processo de variação e mudança linguística quanto no processo de ensino de Língua Portuguesa na escola.

A fim de cumprir o proposto enunciado neste estudo, nosso trabalho está estruturado da seguinte forma: além desta primeira seção introdutória, destacamos alguns aspectos concernentes aos pressupostos teóricos da 
pesquisa na seção "Pressupostos teóricos"; em "Metodologia da pesquisa", descrevemos a metodologia desenvolvida para a realização deste estudo; analisamos e comentamos os resultados obtidos na seção "Análise e discussão dos dados"; encerramos as discussões levantadas acerca do que pensam os alunos de Letras sobre língua, variação e ensino na seção "Considerações finais".

\section{Pressupostos Teóricos}

A Teoria da Variação e Mudança Linguística, também conhecida como Sociolinguística Variacionista, surge a partir dos trabalhos de Weinreich, Labov e Herzog (2006) e Labov (2008) e trata da variação e da mudança linguística, contemplando os usos variáveis de fenômenos linguísticos em seu contexto social. Tal proposta distancia-se dos estudos linguísticos que consideram a língua como um sistema de normas abstratas, externa ao falante e independente do contexto social e mostra que é na heterogeneidade da língua que se deve buscar a estrutura e o funcionamento desse sistema, defendendo a ideia de que a língua é dotada de uma heterogeneidade sistemática, uma heterogeneidade ordenada.

A solução, argumentaremos, se encontra no rompimento da identificação de estruturalidade [structuredness] com homogeneidade. A chave para uma concepção racional da mudança lingüística - e mais, da própria língua - é a possibilidade de descrever a diferenciação ordenada numa língua que serve a uma comunidade. Argumentaremos que o domínio de um falante nativo [nativelike command] de estruturas heterogêneas não tem a ver com multidialetalismo nem com 'mero' desempenho, mas é parte da competência lingüística monolíngüe. Um dos corolários de nossa abordagem é que numa língua que serve a uma comunidade complexa (i.e., real), a ausência de heterogeneidade estruturada é que seria disfuncional (WEINREICH; LABOV; HERZOG, 2006, p.36).

A língua passa a ser vista pelos sociolinguistas como inerentemente variável e a variação e a mudança linguística passam a ser seus objetos de 
estudo e análise, passando toda a língua a apresentar variação, que é potencialmente um desencadeador de mudança. Pesquisas linguísticas realizadas sob o arcabouço teórico-metodológico da Sociolinguística Variacionista (cf. LABOV, 2008) trabalham com a língua em uso dentro de uma comunidade de fala real, uma vez que a língua é uma propriedade da comunidade (é social), permitindo, assim, a explanação de até cinco problemas propostos pela teoria variacionista, a saber, restrição, transição, encaixamento, avaliação e implementação das formas variantes.

A análise desses problemas tem gerando, desde a década de 1970, descrições sobre diferentes fenômenos linguísticos variáveis nos diferentes níveis de análises linguísticas em diversas variedades do português brasileiro e nas modalidades falada e escrita. Essas descrições não só têm permitido explicar o motivo de determinada comunidade de fala usar certas formas linguísticas e não outras quando faz uso da língua, como também têm mostrado que há uma distância entre a língua que falamos e a língua que nos serve de modelo no processo de ensino/aprendizagem, tendo em vista que o ambiente escolar tende a priorizar uma modelo de língua que não condiz com a realidade sociolinguística do aluno.

Um dos maiores desafios das aulas de Português diz respeito, sem dúvida, ao tratamento da variação linguística e, fundamentalmente, aos saberes gramaticais - permeados por diferentes normas linguísticas - que devem estar presentes na escola. Com o amplo acesso dos brasileiros aos bancos escolares [...] a multifacetada realidade brasileira, em todas as suas expressões socioculturais, reflete-se na produtiva e saudável convivência de diversas variedades linguísticas na vida escolar. Conhecer essa realidade plural ocupou e ocupa a agenda dos estudos sociolinguísticos brasileiros [...]. (MARTINS; VIEIRA; TAVARES, 2014, p. 9).

Dessa forma, ao considerar a língua como historicamente situada e heterogênea e focar na análise da língua em uso em diversas situações de interação social, a Sociolinguística também se distancia dos modelos de ensino que adotam uma concepção abstrata e homogênea de língua e postula que o ensino/aprendizagem de Língua Portuguesa precisa levar em consideração a 
diversidade linguística do português brasileiro e não apenas aquele padrão cultuado pela classe social de maior prestígio. Sendo, portanto, tarefa da escola valorizar a multiplicidade linguística e combater o preconceito linguístico, através do reconhecimento de que a língua é uma atividade social e do trabalho com o valor social das formas variantes.

O trabalho, no ambiente escolar, com a variação linguística e com o valor social atribuído às formas variantes, leva o professor a adotar uma concepção de língua que a considera como real, dinâmica e multifacetada, não havendo, assim, supremacia linguística entre as línguas e nem entre as variedades de uma mesma língua, pois, o que existe, de fato, é uma valorização social em relação às variedades linguísticas pela sociedade, o que confere a algumas línguas e a algumas variedades linguísticas prestígio social e a outras, estigma, preconceito, o que significa considerar, conforme pontuou Gnerre (1998, p. 6), que “uma variedade lingǘstica 'vale' o que 'valem' na sociedade os seus falantes".

No entanto, o ensino de Língua Portuguesa nas escolas brasileiras tende a adotar uma atitude tradicional, prescritiva e alienada da realidade sociolinguística brasileira, trabalhando com uma concepção homogênea de língua, que considera apenas como válida a norma posta nos manuais tradicionais, que em nada se aproxima da língua em uso pelos falantes em diversas situações comunicativas. Essa postura tem levado muitos docentes não só a confundirem o ensino de português com um ensino de uma norma padrão abstrata, como também a acreditarem que existe uma única forma "certa" de uso da língua e que seja função da escola "consertar" a fala do aluno para evitar que ele escreva "errado".

Crenças como essas levam o ambiente escolar a desvalorizar a fala do aluno e a fala da sua comunidade, desvalorização que tem implicações diretas no ensino de Língua Portuguesa. Para que essa postura comece a ser mudada, a escola e o professor precisam se livrar desses mitos presentes na sociedade e no ambiente escolar; para tanto, é preciso que haja reflexões e indagações dos docentes de Língua Portuguesa sobre as crenças e atitudes em relação às concepções de língua e de ensino, o que os levará a refletir sobre a concepção de língua que assumem e como desempenham a sua prática docente. Isso aponta que as discussões sobre crenças e atitudes linguísticas são essenciais ao se tratar de ensino de Língua Portuguesa. 
O estudo sobre crenças e atitudes linguísticas de professores de Língua Portuguesa se faz necessário por revelar o que eles pensam sobre a língua e, dessa maneira, o modo como avaliam a língua que usam e a língua que ensinam tem consequências diretas em sua prática docente, uma vez que avaliações negativas em relação à língua e crenças do tipo "português é muito difícil", "brasileiro não sabe português" e "é precisa saber gramática para falar e escrever bem" levam os professores a adotarem em sala de aula um ensino pautado nos moldes tradicionais, que têm como principal objetivo fazer o aluno se apropriar de uma norma padrão com o argumento de que essa norma o habilita a falar e a escrever bem.

A avaliação linguística é um dos itens que precisa passar a ter destaque nas discussões contemporâneas sobre o trabalho escolar com a língua materna, já que ela desencadeia o processo de construção de julgamentos subjetivos do falante em relação a sua língua, a seu dialeto e ao de seu interlocutor na construção das chamadas atitudes linguísticas (CYRANKA, 2014, p. 132).

Para compreender as atitudes de professores de Língua Portuguesa perante a língua que ensinam é importante, primeiramente, conhecer suas crenças perante esse objeto, ou seja, o que pensam em relação à língua, variação e ensino. Para tanto, é necessário esclarecer o que se entende por crenças e atitudes linguísticas. De acordo com Labov (2008), crenças podem ser entendidas como "um conjunto uniforme de atitudes frente à linguagem que são partilhadas por quase todos os membros da comunidade de fala, seja no uso de uma forma estigmatizada ou prestigiada da língua em questão" (p. 176). O autor relaciona crença e atitude linguística, dizendo ser a segunda uma manifestação da primeira.

No ensino de língua, Cyranka (2007) pontua que o que interessa é a "crença sobre", ou seja, "a posição em que os professores e os alunos colocam os objetos (língua, linguagem, variação e aprendizagem lingüística) dentro da dimensão avaliativa, posição essa que, em última instância, leva à atitude deles em relação a esses objetos" (p. 25). Desse modo, a atitude linguística pode ser compreendida como resultado de convicções que a escola, os professores e os alunos possuem sobre a língua, variação e ensino. A 
autora também destaca que as crenças exercem grande influência nas atitudes dos falantes, e estas, por sua vez, manifestam aquelas, sendo as crenças entendidas como construtos do contexto.

Garbuio (2006, p. 90) também argumenta que as crenças "são construídas a partir da história do indivíduo e a partir de sua interação com o meio, além de poder admitir graus", sendo, portanto, dinâmicas. Mais do que graduais, as crenças que os indivíduos possuem são dinâmicas e podem ser (re)significadas, o que geraria também uma mudança na atitude desses indivíduos perante o objeto avaliado. Santos (1996) também pontua que as crenças estão passíveis a mudanças, o que implica considerar que a atitude de um falante pode ser alterada se forem alteradas as suas crenças. A autora define crença como uma "convicção íntima, uma opinião que se adota com fé e certeza", ao passo que atitude é entendida como

uma disposição, propósito ou manifestação de intento ou propósito. Tomando atitude como manifestação, expressão de opinião ou sentimento, chega-se à conclusão de que nossas reações frente a determinadas pessoas, a determinadas situações, a determinadas coisas seriam atitudes que manifestariam nossas convicções íntimas, ou seja, as nossas crenças em relação a essas pessoas, situações ou coisas (SANTOS, 1996, p. 8).

Isso significa considerar que, em um contexto de sala de aula em que os alunos acreditam que falam mal e errado a sua própria língua ou que a língua é muito difícil, se o professor de Língua Portuguesa promover discussões sobre esses temas, considerando a diversidade sociolinguística da Língua Portuguesa, essas crenças podem ser (re)significadas. Para tanto, os professores precisam, conforme pontua Faraco (2008), adotar uma "pedagogia da variação lingüística”, o que significa não só considerar como válidas as variedades linguísticas que os alunos levam para a escola, mas também trabalhar as variedades cultas da língua, com o objetivo de ampliar a competência comunicativa dos alunos.

É papel da escola trabalhar as variedades linguísticas no sentido de conscientizar os alunos acerca do valor social das formas variantes e do uso adequado dessas formas ao contexto (sócio)comunicativo, mas, para o 
desenvolvimento desse trabalho, os professores de Língua Portuguesa precisam se desvincular de crenças equivocadas e de atitudes obsoletas atreladas ao ensino dessa língua. Nesse sentido, "tratar da importância e contribuição da variação linguística na escola hoje é tratar, necessariamente, do lugar e da forma de lidar com dados variáveis na formação dos alunos de Letras, seja com variantes reais da fala, seja em dados não vernáculos de língua escrita literária" (BARBOSA, 2015, p. 252).

\section{Metodologia da Pesquisa}

O presente trabalho tem como objetivo analisar as crenças e atitudes linguísticas dos alunos do curso de Letras, futuros professores de Língua Portuguesa, a respeito do ensino de Língua Portuguesa nas escolas. Para tanto, entrevistamos, durante os semestres letivos 2015/2 e 2016/1, 18 acadêmicos do curso de Letras da Universidade Federal de Alagoas - Campus do Sertão, que estudaram e residem no sertão de Alagoas. Durante as entrevistas, os alunos cursavam o $7^{\circ}$ período do curso e estavam matriculados na disciplina de Estágio Supervisionado III, que tem como objetivo articular teoria e prática docente.

Estágio Supervisionado III - os estagiários serão encaminhados para instituições de ensino que ofertem turmas de $6^{\circ}$ ao $9^{\circ}$ anos do Ensino Fundamental, objetivando a prática do ensino e pesquisa, como também a vivência das atividades cotidianas da escola nos âmbitos da língua oral, escrita e digital, nos eixos de leitura e produção de textos, literários e não literários, subsidiados pela análise linguística e literária nessa etapa da Educação Básica. (UNIVERSIDADE FEDERAL DE ALAGOAS, Campus Sertão, 2014, p. 76).

$\mathrm{O}$ instrumento utilizado para obter os dados da pesquisa foi um questionário composto por 12 questões abertas, a saber:

1. Você acha que o Português é uma língua difícil?

2. O que é, para você, saber Lingua Portuguesa?

3. Para você, o melhor e mais correto jeito de falar é o que está descrito na gramática? 
4. Na sua opinião, pessoas que não vão à escola falam errado?

5. Na sua opinião, é importante ensinar gramática na escola?

6. Você acha que o ensino de Lingua Portuguesa na escola deve ocupar-se com a diversidade dos usos linguísticos adequados a diferentes situaçoes comunicativas?

7. Na sua opinião, uma das funções da escola é corrigir a fala dos alunos?

8. De modo geral, como você avalia o ensino de Lingua Portuguesa?

9. Na escola que você estudou, como eram as aulas de Lingua Portuguesa?

10. O que é, para você, estudar Lingua Portuguesa?

11. O que é, para você, ensinar Lingua Portuguesa?

12. Você acha que sua formação acadêmica o habilita para ser professor de Lingua Portuguesa?

Essas questões foram adaptadas de Barbosa e Cuba (2015) e Silva e Botassini (2015), e tinham como objetivo mensurar o que pensam os alunos de curso de Letras da Universidade Federal de Alagoas - Campus do Sertão sobre língua, variação e ensino. As questões buscavam aferir as crenças e atitudes linguísticas desses alunos - positivas ou negativas -, a fim de tentar construir o universo escolar desses futuros professores, tendo em vista que associar reflexões sociolinguísticas com discussões sobre crenças e atitudes linguísticas "pode propiciar a compreensão mais adequada das ações que guiam o comportamento dos indivíduos em relação à sua fala e à fala do(s) outro(s)" (BOTASSINI, 2015, p. 128).

Para a discussão dos dados, além da análise qualitativa das respostas dos alunos sobre as questões abordadas, apresentamos, na exposição dos resultados, gráficos com resultados quantitativos. Fernández e Díaz (2002) argumentam que o emprego de análises qualitativas e quantitativas em uma pesquisa pode ajudar a corrigir distorções associadas a cada método de análise, tendo em vista que uma investigação qualitativa se caracteriza por ser subjetiva, exploratória, indutiva e não generalizável, ao passo que uma investigação quantitativa, por ser objetiva, confirmatória, inferencial, dedutiva e generalizável.

\section{Análise e Discussão dos Dados}

Bagno (2015), no livro Preconceito Linguístico, discorre sobre oito mitos presentes na sociedade e, principalmente, no ambiente escolar sobre o que o 
brasileiro tende a pensar a respeito da sua língua. Dentre esses mitos, há o mito $n^{\circ} 3$ - português é muito difícil -, que está diretamente relacionado ao mito de que "brasileiro não sabe português", uma vez que existe aqui uma associação entre a língua que falamos e as normas prescritas nos manuais normativos, logo, saber português é saber as regras gramaticais apresentadas nesses manuais.

Para muita gente, 'saber português' é saber o que é uma oração subordinada substantiva objetiva direta reduzida de infinitivo ou saber distinguir um complemento nominal de um adjunto adnominal. É lamentável, para dizer o mínimo, que a imagem da língua tenha sido empobrecida desse jeito, reduzida a uma nomenclatura profusa e confusa e a exercícios mecânicos de análise sintática e morfológica, práticas que se revelam, ao fim e ao cabo, inúteis e irrelevantes para de fato levar alguém a se valer dos muitos recursos que a língua oferece (BAGNO, 2015, p. 63).

Ao perguntarmos aos alunos, na primeira questão, Você acha que o Português é uma língua difícil?, verificamos, conforme o Gráfico 1, que a maioria dos alunos de Letras acredita que sim - 56\% contra 44\% que acreditam que não, dados que confirmam a crença de que os falantes brasileiros tendem a achar o português uma língua difícil. Ao analisarmos as respostas dos alunos que acreditam ser o português uma língua difícil, verificamos, conforme podemos observar nos comentários (1), (2) e (3), a associação e/ou confusão entre a língua e as regras prescritas nos manuais normativos. 


\section{Você acha que o Português é uma língua difícil?}

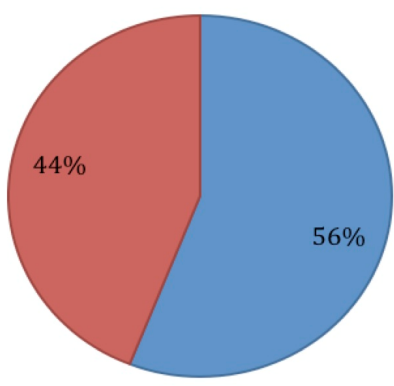

$\square \operatorname{sim}$

$\square$ não

Fonte: Elaborado pela autora.

Gráfico 1 - Resultado das respostas à questão 1

(1) porque há muitas regras (Informante 7)

(2) gramaticalmente sim, pois tem muitas regras (Informante 14)

(3) sim pois fui escolarizado de forma que tinha que memorizar infinitas regras que eu mesmo, falante da língua, não usava e, portanto, não compreendia (Informante 10)

Essas respostas reforçam a crença, gerada principalmente no ambiente escolar, de que saber português é apenas saber as normas prescritas nas gramáticas tradicionais que servem de modelo ao ensino de Língua Portuguesa nas escolas, sendo, portanto, objetivo da escola "dar" ao aluno uma "língua" que ele não possui, reduzindo, assim, tanto a língua quanto o ensino de português, à gramática tradicional, o que nos conduz à ideia de língua como homogênea e de um ensino que nos remete apenas à codificação tradicional da língua, conforme pontua o informante 12 no comentário (4).

(4) [... não há língua difícil para um falante nativo de tal língua, o que acontece é que pela insistência em se ensinar apenas gramática normativa na escola o senso comum acha que o português é apenas 
normas e regras e estas muitas vezes não estão inseridas em seu contexto cotidiano, por isso o achismo (Informante 12)

Em seguida, com o objetivo de aferir as crenças dos alunos sobre o que deveria ser o conhecimento linguístico dos falantes, perguntamos: O que é, para você, saber Lingua Portuguesa?, e verificamos que as respostas oscilam entre fazer uso da linguagem em diferentes situações comunicativas, reconhecendo, assim, a diversidade linguística e/ou ter conhecimento e saber as regras prescritas nas gramáticas, conforme podemos observar nos comentários (5), (6) e (7), o que nos leva a argumentar que os alunos ainda acreditam na crença de que saber língua é saber norma da gramática tradicional.

(5) é conhecer o uso da língua em determinadas situações comunicativas (Informante 7)

(6) saber língua portuguesa é compreender a diversidade da linguagem, assim como a fala, é entender o que é o certo, que não existe língua melhor, nem pior, nem difícil, saber que o certo é respeitar a diversidade presente na sociedade (Informante 17)

(7) não é apenas saber regras e normas do bem falar, mas também que não existe certo e errado, mas variações linguísticas e que tudo depende do contexto (Informante 13)

As palavras mais utilizadas pelos alunos para conceituar os saberes que envolvem o conhecimento da Língua Portuguesa pelos falantes brasileiros, conforme Figura 1, giram em torno não só dos verbos saber, comunicar, entender e compreender, como também dos nomes lingua, regras, variacõoes, comunicações, gramática, diversidade, certo, gramaticais, o que nos mostram que, apesar da consciência da diversidade linguística, os alunos ainda estão ligados à ideia do senso comum de que saber língua é saber e dominar regra de gramática. 


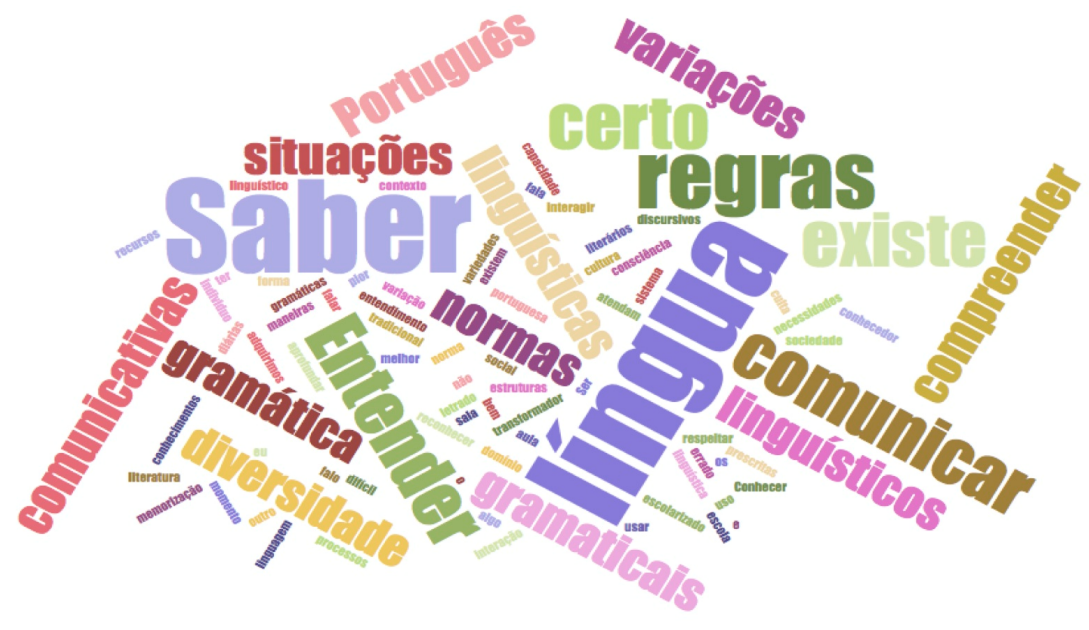

Fonte: Elaborada pela autora.

Figura 1 - Nuvem de palavras a partir das respostas dos alunos à questão 2

As razões estão, em grande parte, ligadas à insistência da nossa tradição escolar em não reconhecer a legitimidade do vernáculo dos alunos, impondo-lhes o domínio da norma-padrão como condição de sucesso. Isso com o agravante de não desconhecer o seu vernáculo, mas também de considerá-lo errado, nocivo, devendo ser esquecido (CYRANKA, 2014, p. 142).

Tendo em vista a crença de que a língua é homogênea, o que nos remete à existência de uma "fala correta" e de uma "escrita correta", que são ensinadas na escola e explicadas nas gramáticas, logo as pessoas que falam "corretamente" são aquelas mais instruídas, pois tiveram acesso a essa maneira de uso "correto" da língua, perguntamos, na terceira e na quarta questões, respectivamente: Para você, o melhor e mais correto jeito de falar é o que está descrito na gramática? e Na sua opinião, pessoas que não vão à escola falam errado?

As respostas dos alunos a essas questões foram categóricas em não concordar com esses questionamentos, mostrando, assim, uma atitude positiva em relação à diversidade linguística, pois não só acreditam que, em termos 
linguísticos, não há o melhor ou o pior jeito de falar, pois a maneira de falar de uma pessoa muda de acordo com a região, o grupo social em que convive e com a situação comunicativa em que está participando, como também não acreditam que as pessoas que não frequentaram a escola falam errado, mas diferente, conforme podemos observar nos comentários (8) e (9):

(8) não acho que seja a melhor e a mais correta forma de falar aquela que a gramática prega, porque ao dizer e acreditar nisso estaria desconsiderando tudo que está linguisticamente distante dessa norma da gramática (Informante 12)

(9) as pessoas que não vão à escola falam diferente, seguem outra norma que não é a da gramática tradicional, mas que está linguisticamente correta (Informante 3)

Os alunos mostram uma atitude positiva em relação à pluralidade de normas que constitui a Língua Portuguesa, revelando, assim, a aceitação de que, em termos linguísticos, as normas linguísticas se equivalem, pois são organizadas e complexas, logo não há a forma certa e a forma errada, mas a língua em uso que varia e muda a depender de fatores extralinguísticos. Essa postura é importante para a adoção de uma abordagem de língua como um conjunto de variedades na escola e para evitar o estímulo ao preconceito linguístico.

O preconceito linguístico se baseia na crença de que só existe [...] uma única língua portuguesa digna desse nome e que seria a língua ensinada nas escolas, explicada nas gramáticas e catalogada nos dicionários. Qualquer manifestação linguística que escape desse triângulo escola-gramáticadicionário é considerada, pela ótica do preconceito linguístico, 'errada, feia, estropiada, rudimentar, deficiente’, e não é raro a gente ouvir que ‘isso não é português’ (BAGNO, 2015, p. 64).

Partindo do pressuposto de que uma das funções do ensino de Língua Portuguesa é promover a reflexão sobre a língua e a linguagem, habilitando o aluno a usar a língua em diferentes situações comunicativas, perguntamos, 
na quinta questão: $\mathrm{Na}$ sua opinião, é importante ensinar gramática na escola?, e verificamos que todos os alunos concordam que o estudo gramatical deve estar presente no processo de ensino/aprendizagem de língua, veiculando a relevância desse estudo a aprendizagem de uma nova maneira de uso da língua, conforme podemos observar nos comentários (10) e (11).

(10) para que o aluno conheça mais uma forma de manifestação da língua (Informante 2)

(11) para mostrar ao aluno que existe a norma culta da língua e que o mesmo precisa adequar a sua fala de acordo com o contexto em que esteja inserido (Informante 16)

Os alunos também destacam que o ensino de gramática nas escolas deve sempre partir do pressuposto de que a gramática normativa não é a língua, mas apenas uma norma que contém as formas linguísticas que são prestigiadas socialmente, norma essa que pode auxiliar o falante a lidar com textos mais formais, logo esse ensino deve promover a reflexão de uso dessa norma e não ser regido pelas noções de "certo" e "errado" e se restringir apenas às atividades classificatórias desvinculadas do uso real da fala e da escrita, conforme podemos observar nos comentários (12), (13) e (14).

(12) o ensino de gramática é importante para que os alunos entendam de que maneira utilizamos determinadas formas no ato de fala e da escrita, principalmente mais formais, o que não deve acontecer é o ensino de gramática ser o único modo de se dar aula de Língua Portuguesa e nem de fazer da gramática normativa a língua (Informante 12)

(13) o aluno dever ter conhecimento sobre a norma padrão, porém deve saber que existem outras normas além dela (Informante 1)

(14) dever ser ensinada gramática nas escolas, porém a forma de ensino, a sua metodologia é que dever ser repensada, de maneira a refletir sobre a língua (Informante 10) 
Há aqui também uma preocupação dos alunos em dar ênfase à questão de como as questões gramaticais devem ser abordadas no ambiente escolar, tendo em vista que, tradicionalmente, as variedades linguísticas são esquecidas e deixadas de lado do objeto de ensino na maioria das aulas de Língua Portuguesa, que considera a variação linguística como um desvio da norma culta e adota um ensino baseado na norma-padrão, um ensino que se revela tradicional, prescritivo e alienado da diversidade linguística.

a escola precisa trabalhar com gramática (i) contemplando o funcionamento de recursos linguísticos em diferentes níveis (fonéticofonológico, morfológico, sintático, semântico-discursivo) e (ii) propiciando condições para que o aluno tenha acesso à norma culta da língua que é a variedade de prestígio na sociedade, e consequentemente, à possibilidade de ascensão social. O que se coloca em discussão é: qual gramática ensinar? e de que maneira ensiná-la? (GÖRSKI; COELHO, 2009, p.83)

A partir dessa discussão, perguntamos, na sexta questão: Você acha que o ensino de Lingua Portuguesa na escola deve ocupar-se com a diversidade dos usos linguísticos adequados a diferentes situações comunicativas? e todos os alunos disseram que sim, mostrando uma atitude positiva em relação ao tratamento da língua como uma estrutura inerentemente variável, o que significa aceitar um ensino de língua centrado na adequação linguística, no uso formal e informal da língua a depender da situação comunicativa, conforme podemos observar no comentário (15).

(15) isso é de extrema importância que as escolas passem para seus alunos como a língua é usada em diferentes regiões do país e que existem diversos usos linguísticos de acordo com cada situação (Informante 8)

A escola pode e deve fazer esse trabalho desde os primeiros anos do ensino fundamental, levando os alunos a se perceberem como falantes legítimos de sua língua materna e a perceberem nela a expressão da cultura de seu grupo social e de outros diferentes com os quais devem 
interagir. Nesse processo, as diferentes normas linguísticas vão sendo reconhecidas, dos dialetos populares às variedades cultas, sem dúvida, mas mais prestigiadas (CYRANKA, 2014, p, 140).

Na sétima questão, perguntamos aos alunos se, Na sua opinião, uma das funções da escola é corrigir a fala dos alunos?, e verificamos, conforme Gráfico 2, que $94 \%$ acham que a escola não deve adotar essa postura, pois não há a língua "certa" a ser ensinada, mas, sim, formas linguísticas adequadas e inadequadas a certas situações comunicativas. Essa postura corrobora a premissa de que o papel da escola não é corrigir a fala dos alunos, mas ensinar quando, como e onde usar a norma culta, sem desmerecer a variedade linguística dos alunos.

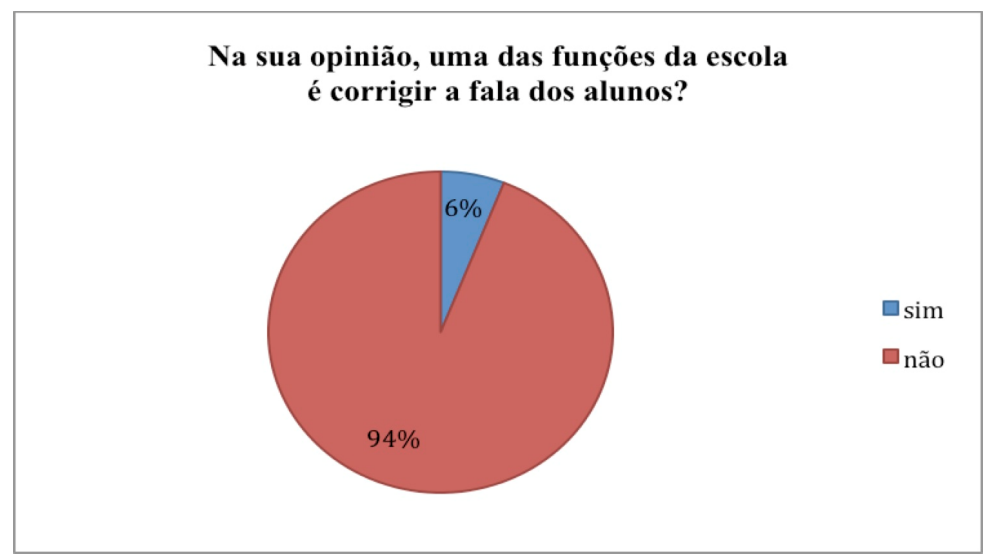

Fonte: Elaborado pela autora.

Gráfico 2 - Resultados das respostas à questão 7

Interessante destacar a ênfase dada nas respostas à questão de que a variação linguística pode ocorrer não só em função da origem geográfica do falante, tendo em vista que é apenas esse tipo de variação que tende a ser focado nos materiais didáticos e nas aulas de português, como também pode ser social, ou seja, variação concernente à organização socioeconômica e cultural da comunidade, e estilística, variação que se relaciona ao uso da língua em diferentes situações comunicativas, caracterizando, assim, 
a língua como formal e/ou informal, conforme podemos observar no comentário (16).

(16) de maneira alguma, pois cada aluno fala de acordo com a sua região e o seu grupo social, porém é preciso mostrar como a língua deve ser usada em situações mais formais, principalmente, a escrita mais monitorada (Informante 8)

Em seguida, na oitava questão, perguntamos: De modo geral, como você avalia o ensino de Lingua Portuguesa?, e verificamos, conforme Gráfico 3, que $67 \%$ avaliam como regular, $28 \%$ como ruim e apenas $5 \%$ como bom. Essa avaliação tão negativa, segundo os alunos, deve-se ao fato de ser o ensino escolar centrado na noção de língua como homogênea, considerando apenas como material de ensino o livro didático e/ou a gramática normativa. É um ensino que tem como foco fazer o aluno decorar as regras das gramáticas tradicionais, conforme podemos observar nos comentários (17), (18) e (19).

\section{De modo geral, como você avalia o} ensino de Língua Portuguesa?

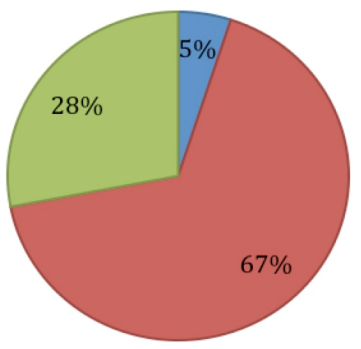

$\square_{\text {bom }}$

$\square$ regular

$\square$ ruim

Fonte: Elaborado pela autora.

Gráfico 3 - Resultado das respostas à questão 8

(17) em geral, o ensino baseia-se na prescrição de regras e não na reflexão da língua, tendo o livro didático e a gramática como únicos materiais (Informante 10) 
(18) o ensino de Língua Portuguesa nas escolas ainda enfatiza apenas as regras gramaticais, mesmo quando se trabalha com textos nas aulas (Informante 7)

(19) pelo conhecimento obtido com o estágio de observação, os docentes utilizam-se apenas do livro didático, mais especificamente o ensino de gramática, sem dar ênfase ao uso da língua (Informante 15)

As atividades didáticas, nesse tipo de abordagem, costumam ser basicamente classificatórias, desvinculadas do uso real da língua, regidas pelas noções de 'certo' e 'errado', em que certo é o que está de acordo com as regras de tais gramáticas, ao passo que tudo o que não se conformar a essas regras é taxado de erro e deve ser corrigido. Tal quadro, embora identificado como 'tradicional', é ainda encontrado nos dias de hoje em muitas escolas (GÖRSKI; COELHO, 2009, p. 74).

$\mathrm{Na}$ nona questão, perguntamos aos alunos: Na escola que você estudou, como eram as aulas de Lingua Portuguesa? e verificamos, conforme Gráfico 4, que $77 \%$ julgam as aulas como regulares, $11 \%$ como boas, $6 \%$ como ruins e $6 \%$ como péssimas, revelando, novamente, uma avaliação negativa em relação ao ensino de Língua Portuguesa. Essa avaliação negativa, conforme podemos observar nos comentários (20) e (21), está atrelada ao fato de as aulas se restringirem apenas à exploração dos conteúdos gramaticais, mostrando que o que impera nas escolas é um ensino tradicional de língua. 


\section{Na escola que você estudou, como eram as aulas de Língua Portuguesa?}

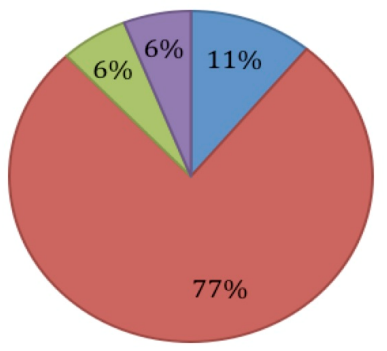

$\square$ boas

$\square$ regulares

$\square$ ruins

$\square$ péssimas

Fonte: Elaborado pela autora.

Gráfico 4 - Resultado das respostas à questão 9

(20) eram apenas aulas voltadas para o ensino da gramática tradicional (Informante 13)

(21) os professores se preocupavam apenas em ensinar pura gramática, como se apenas ela fosse importante para a vida (Informante 8)

Esses dados apontam que embora haja uma profícua pesquisa na área da Sociolinguística apontando a necessidade de abordar a variação linguística na escola, com o reconhecimento da diversidade linguística já presente nos documentos oficiais de diretrizes para educação, o modo como lidar com a pedagogia da variação linguística ainda permanece um problema na escola. Segundo Faraco (2008), talvez isso aconteça por não termos discutido suficiente e publicamente a heterogênea realidade linguística existente no Brasil.

A diversidade linguística está presente nas políticas públicas, como nos documentos norteadores das diretrizes curriculares, como os Parâmetros Nacionais de Língua Portuguesa (PCN) e a Base Nacional Curricular Comum (BNCC), nos documentos norteadores da avaliação de materiais, como o edital do Programa Nacional do Livro Didático 
de Língua Portuguesa (PNLD), e nos programas de avaliação dos cursos de formação inicial, como no edital do Exame Nacional de Desempenho dos Estudantes (Enade). O grande gargalo, no entanto, é chegar à sala de aula (FREITAG, 2016, p. 14).

Daqueles que avaliaram as aulas como boas, 11\% argumentaram que, nas escolas que estudaram, as aulas de Língua Portuguesa estavam voltadas à realidade linguística do aluno, ou seja, os professores tentavam ir além dos conteúdos e exercícios postos no material didático e traziam para aulas discussões sobre a língua em uso pelos alunos, conforme podemos observar no comentário (22). Essa avaliação mostra que os alunos têm consciência que um ensino que proporcione a reflexão sobre a língua e seus usos desconstrói falsas crenças e incentiva uma educação sociolinguística.

(22) tive professores que saíam um pouco do que era posto nos livros didáticos, que tentavam adaptar os conteúdos das aulas à nossa realidade linguística, que exploravam mais a discussão sobre língua, principalmente no ensino médio (Informante 2)

Em seguida, na décima questão, perguntamos: O que é, para você, estudar Lingua Portuguesa?, e verificamos que os alunos acreditam que é ir além do que a gramática normativa impõe, que não é apenas aprender a norma culta da língua, mas reconhecer que a língua é variável e que, dependendo do contexto social, é possível utilizar uma fala ou uma escrita mais formal ou informal, é refletir sobre a língua que usam, não atribuindo, assim, ao ensino de Língua Portuguesa, o papel de "dar" ao aluno uma língua que ele ainda não possui, conforme podemos observar nos comentário (23), (24) e (25).

(23) é ampliar os recursos linguísticos (Informante 12)

(24) estudar Português é estudar todas as possibilidades de manifestações da língua, principalmente em relação à fala (Informante 2) 
(25) é aprender maneiras de adequar a língua de acordo com o contexto em que esteja inserida, é reconhecer variações linguísticas e normas cultas (Informante 16)

As palavras mais utilizadas nas respostas à questão 10 - variação e gramática, conforme Figura 2, mostram a ênfase que os alunos procuraram dar em afirmar que estudar Língua Portuguesa na escola não é decorar regras de gramática, mas é ir além da gramática tradicional, é reconhecer a variação como constitutiva da língua, sendo, portanto, a situação comunicativa o lugar que nos diz como a língua dever ser usada, revelando, assim, uma atitude positiva à adoção de uma pedagogia da variação linguística na escola.

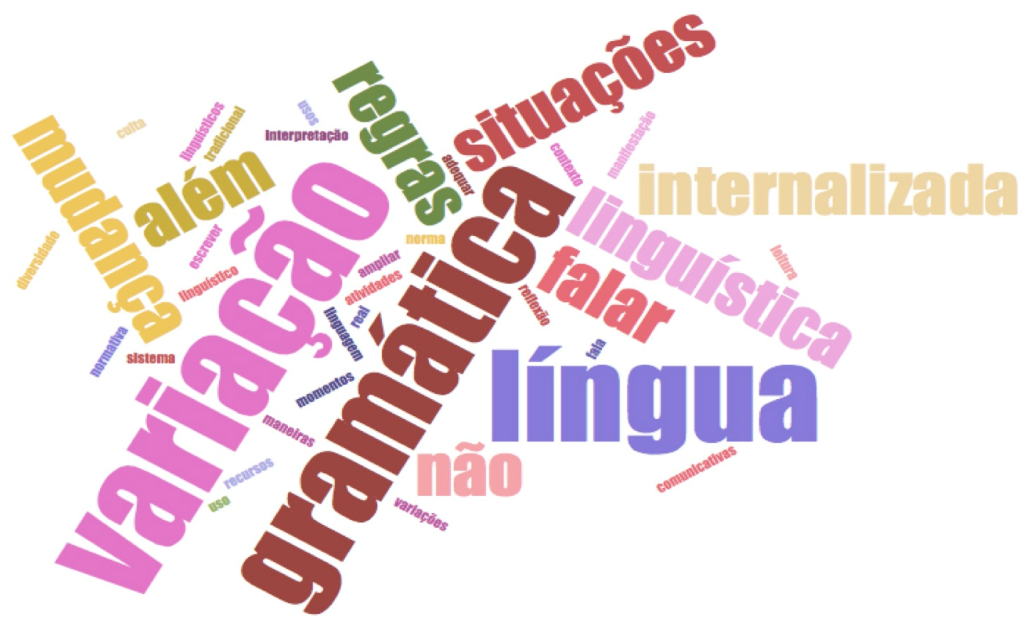

Fonte: Elaborada pela autora.

Figura 2 - Nuvem de palavras a partir das respostas dos alunos à questão 10

Em seguida, na décima primeira questão, perguntamos aos alunos: $O$ que é, para você, ensinar Lingua Portuguesa?, e verificamos, conforme podemos observar nos comentários (26), (27) e (28), que as respostas caminham na mesma direção da questão anterior, ou seja, o ensino de Língua Portuguesa 
deve ser um momento em que professor e alunos reflitam sobre as diversas possibilidades de uso da língua nas modalidades falada e escrita, através de atividades de leitura, escrita, interpretação, a fim de habilitar o aluno a usar a língua em diferentes situações comunicativas.

(26) ensinar Língua Portuguesa é demostrar para o aluno as mais diversas formas que a língua pode se manifestar, para que possam adequar suas falas as mais diferentes situações (Informante 2)

(27) é refletir com os alunos sobre o sistema linguístico da Língua Portuguesa, levando em consideração as variações que esta mesma língua pode ter (Informante 10)

(28) é não passar o ano todo ensinando gramática e fazendo exercícios sobre isso, mas abrir espaço para as aulas de leitura, interpretação, reflexão sobre a língua usada pelos alunos (Informante 18)

Para tanto, conforme observamos na Figura 3, as palavras mais utilizadas foram uso, gramática e não, uma vez que os alunos sempre procuravam reforçar a ideia de que o ensino não deve ficar restrito ao conteúdo da gramática tradicional e nem deve ser um ensino pautado em decorar regras, como podemos observar no comentário (29), mas um ensino centrado no uso da língua, que leve em consideração a variação linguística e as diferentes situações comunicativas, contrapondo, assim, ao que tende acontecer na maioria das salas de aula de Língua Portuguesa. 


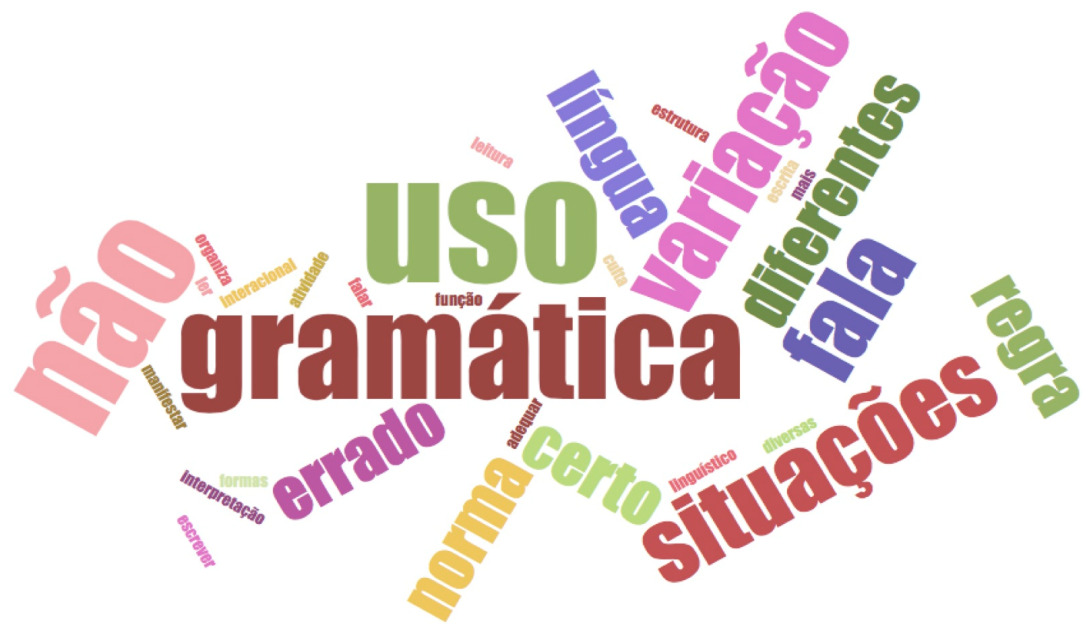

Fonte: Elaborada pela autora.

Figura 3 - Nuvem de palavras a partir das respostas dos alunos à questão 11

(29) é fazer com que os alunos compreendam que não é apenas regras que eles precisam saber para falar e escrever bem (Informante 13)

Por fim, na décima segunda questão, perguntamos: Você acha que sua formação acadêmica o habilita para ser professor de Lingua Portuguesa?, e verificamos, conforme Gráfico 5, que 67\% acreditam que sim, que após o curso estarão aptos ao trabalho docente, ao passo que 33\% responderem que mais ou menos, ora argumentando que ainda precisam estudar mais, ora afirmando que não se sentem preparados totalmente porque não estudaram gramática tradicional na universidade, uma vez que a escola pede sempre esse ensino, conforme podemos observar nos comentários (30), (31) e (32). 


\section{Você acha que sua formação academica o habilita para ser professor de Língua Portuguesa?}

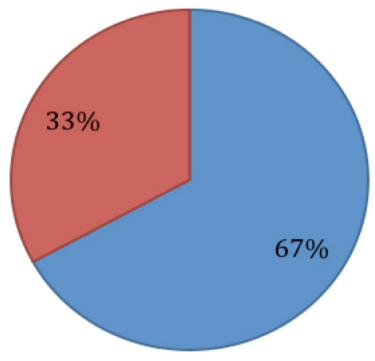

$\square \operatorname{sim}$

$\square$ mais ou menos

Fonte: Elaborado pela autora.

Gráfico 5 - Resultado das respostas à questão 12

(30) preciso estudar muito ainda para não cometer erros recorrentes no ensino, por exemplo, o de querer enquadrar o aluno na gramática puramente (Informante 3)

(31) porque não estudamos a gramática tradicional que é cobrada para dar aula nas escolas (Informante 14)

(32) por se tratar que o mercado de trabalho foca somente na gramática ainda e aqui na universidade não é o foco principal (Informante 5)

Essas respostas mostram que, embora os alunos tenham uma atitude positiva em relação a uma pedagogia que sensibilize os professores para a variação linguística, mostrando que as línguas variam e as variedades precisam ser respeitadas, verificamos ainda uma preocupação com o ensino tradicional; talvez seja uma preocupação em como lidar com dados linguísticos em sala de aula, o que parece indicar que os alunos não estão conseguindo aplicar as teorias sociolinguísticas à analise linguística dos dados em atividades docente. 


\section{Considerações Finais}

A diversidade linguística é uma realidade inegável em qualquer língua, porém a maneira como ela é concebida pelos falantes e abordada no ensino são questões que ainda suscitam inúmeras discussões, uma vez que predomina tanto na sociedade quanto no ambiente escolar a noção de homogeneidade linguística, permanecendo um problema para a escola a adoção da pedagogia da variação linguística. Com o intuito de analisar o que pensam os alunos de Letras da Universidade Federal de Alagoas - Campus do Sertão sobre o processo de ensino/aprendizagem de Língua Portuguesa, mensuramos suas crenças e atitudes linguísticas sobre língua, variação e ensino.

Nossas discussões mostram que, apesar de a maioria dos alunos (56\%) associar língua à gramática normativa, acreditando que português é uma língua difícil porque possui muitas regras, logo saber Língua Portuguesa é dominar as regras prescritas nas gramáticas normativas, verificamos crenças e atitudes positivas em relação à pedagogia da variação linguística. Os acadêmicos acreditam e defendem a ideia de que é papel da escola e do professor de Língua Portuguesa não só reconhecer e trabalhar a variação linguística, mas também habilitar o aluno a usar a língua em diferentes situações comunicativas.

Nossas análises também apontam uma avaliação negativa em relação ao atual ensino de língua, que, segundo os alunos, é centrado apenas na norma-padrão, o que corrobora a afirmação de Faraco (2008, p. 176) de que "não sabemos, de fato, o que fazer com a variação lingüística na escola". A centralidade no ensino gramatical leva os alunos a acreditarem que não estão aptos à atividade docente por não terem, na universidade, a tradicional aula de gramática, o que nos leva a argumentar que precisamos explorar mais análises de dados linguísticos para que os futuros professores possam aplicar teorias aos dados linguísticos.

\section{Referências}

BAGNO, M. Preconceito linguístico. 52. ed. São Paulo: Parábola, 2015. 
BARBOSA, A. Variação linguística no curso de Letras: práticas de ensino. In: ZILLES, A.; FARACO, C. Pedagogia da variação linguística: língua, diversidade e ensino. São Paulo: Parábola, 2015. p. 249-286.

BARBOSA, J.; CUBA, D. Crenças e atitudes linguísticas de alunos do ensino médio em escolas públicas de Uberaba. Todas as Letras, São Paulo, v. 17, n. 1, p. 73-90, jan./abr. 2015.

BOTASSINI, J. O. M. A importância dos estudos de crenças e atitudes para a Sociolinguística. Signum: Estudos da Linguagem, n. 18/1, p. 102-131, p. 102-131, jun. 2015. Disponível em: < http://bit.ly/2jhbpvX>. Acesso em: 15 jun. 2017.

CYRANKA, L. Atitudes lingüísticas de alunos de escolas públicas de Juiz de ForaMG. 2007. Tese (Doutorado em Estudos Linguísticos) - Universidade Federal Fluminense, Niterói.

CYRANKA, L. Avaliação das variantes: atitudes e crenças em sala de aula. In: MARTINS, M.; VIEIRA, S.; TAVERES, A. (Org.). Ensino de português e Sociolinguistica. São Paulo: Contexto, 2014. p. 133-156.

FARACO, C. Norma culta brasileira: desatando alguns nós. São Paulo: Parábola, 2008.

FERNÁNDEZ, S.; DÍAZ, S. Investigación cuantitativa y cualitativa. 2002. Disponível em: <http://bit.ly/1ha1cwK>. Acesso em 18 jun. 2017.

FREITAG, R. M. K. Sociolinguística no/do Brasil. Caderno de Estudos Linguísticos, Campinas, v. 58, n. 3, p. 445-460, set./dez. 2016.

GARBUIO, L. Crenças sobre a língua que ensino: foco na competência implícita do professor de língua estrangeira. In: BARCELOS, A.; ABRAHÃO, M. (Org.). Crenças e ensino de línguas: foco no professor, no aluno e na formação de professores. Campinas: Pontes, 2006.

GNERRE, M. Linguagem, escrita e poder. São Paulo: Martins Fontes, 1998.

GÖRSKI, E.; COELHO, I. Variação linguística e ensino de gramática. Working Papers Linguistica. Florianópolis, v. 10, n. 1, p. 73-91, jan./jun. 2009. 
LABOV, W. Padrões sociolinguisticos. São Paulo: Parábola, 2008 [1972].

MARTINS, M. A.; VIEIRA, S. R.; TAVARES, M. A. Contribuições da Sociolinguística brasileira para o ensino de português. In: MARTINS, M. A.; VIEIRA, S. R.; TAVARES, M. A. (Org.). Ensino de português e Sociolinguística. São Paulo: Contexto, 2014. p. 7-35.

SANTOS, E. Certo ou errado? Atitudes e crenças no ensino da língua portuguesa. Rio de Janeiro: Graphia, 1996.

SILVA, F. B.; BOTASSINI, J. Crenças e atitudes linguísticas: o que pensam os alunos de Letras sobre o ensino de Língua Portuguesa. Letras \& Letras, Uberlândia, v. 31, n. 2, p. 61-85, jul./dez., 2015.

UNIVERSIDADE FEDERAL DE ALAGOAS - Campus do Sertão. Projeto Político-Pedagógico do Curso de Licenciatura em Letras. 2014. Disponível em: <http://bit.ly/2j'TruqU>.

WEINREICH, U.; LABOV, W.; HERZOG, M. Fundamentos empiricos para uma teoria da mudança lingüística. São Paulo: Parábola, 2006 [1968].

Recebido em: 25/06/2016 Aceito em: 05/09/2016 